POZUELO YVANCOS, José María y ARADRA, Rosa María. Teoría del canon y literatura española. Madrid: Cátedra, 2000. 303 p.

\title{
Etnografias imaginárias: literatura, teoria e cânone por
} Pozuelo Yvancos*

\author{
Sabrina Sedlmayer ${ }^{*}$ \\ Gabriel Schünemann ${ }^{* * *}$ \\ Janine Rocha ${ }^{\star \star *}$ \\ Josué Borges de Araújo Godinho ${ }^{* * *}$ \\ Luciano Danilo Silva ${ }^{* * * * *}$ \\ Vinícius Ribeiro Pimentel ${ }^{k+k+k}$ \\ Yara Augusto ${ }^{* *}$
}

Publicado em Madrid, em 2000, Teoría del canon y literatura española, de José María Pozuelo Yvancos - com a colaboração de Rosa Maria Aradra Sanchez - se sobressai em relação a maioria dos livros que se dispõe a trabalhar sobre

\footnotetext{
- Recebido para publicação em setembro de 2005.

"* Professora da Faculdade de Letras/UFMG.

**. Aluno da Graduação da Faculdade de Letras/UFMG.

*. Auna da Graduação da Faculdade de Letras/UFMG.

*.* Mestrando do Pós-Lit - Programa de Pós-Graduação em Letras - Esudos Literários, da Faculdade de Letras/UFMG.

-... Graduado pela Faculdade de Letras/UFMG.

.... Graduado pela Faculdade de Letras/UFMG.

-.* Aluna da Graduação da Faculdade de Letras/UFMG.
} 
o que se convencionou a denominar de "crise da teoria", ou a traçar, diacronicamente, um panorama do estado convulso dos estudos literários nas últimas décadas do século $X X$.

Além de se apartar daqueles a quem Jonathan Culler ironicamente acusou de utilizarem a "retórica da crise" para alavancarem publicações, Yvancos também se afasta da litania chorosa daqueles que acreditam que a emergência dos Estudos Culturais (e a Desconstrução, a Crítica Feminista e os Estudos Pós-Coloniais) obrigatoriamente destronaria os Estudos Literários. Em sua investigação, o teórico espanhol demonstra que o que está irremediavelmente em crise é o sentido tradicional de crítica e o que esta entende por teoria. Privarmo-nos de diagnóstico de valor, não sucumbirmos a uma imagem idealizada do clássico muito menos de uma estabilidade canônica, observar, retrospectivamente, que os estudos literários, em outras épocas, já se debateram com a ciência, a cultura de massas, a psicanálise e outros meios de produção de saberes (recordarmos, por exemplo, do célebre embate, entre Picard e Barthes, ainda nos anos sessenta), também auxiliam na compreensão atual, nesses tempos em que a própria natureza do objeto, a literatura, foi colocada em xeque.

Como fundamentação do seu ponto de vista nã́o apocalíptico, Pozuelo aponta como a semiótica eslava e os estudos polisistémicos já superaram alguns sintomas que ainda hoje estão em debate no circuito norte-americano. Cita, a esse propósito, o texto de Curtius (para confirmar o fosso de comunicação que há entre América e a Europa), Literatura Européia e Idade Média Latina que, décadas anteriores, já apontava linhas de fuga para esse debate contemporâneo.

Outro traço singular desse estudo é o fato de Yvancos ser de Múrcia. Afastado das ressonâncias pós-estruturalistas francesas e dos apelos orgânicos dos Blooms americanos, o 
autor se coloca como uma espécie de outsider ao sugerir deduzir perspectivas teóricas a partir de Tinianov, Moukarovsky, Even-Zohar, Lotman e Bordieu. Mesmo consciente de que "escolher uma teoria não é somente escolher um instrumental metodológico para um objeto definido e inquestionável, mas, sim, escolher um lugar a partir do qual definir esse objeto", o autor oferece uma bibliografia vasta e um mapeamento da problemática, sem cair nos binarismos cristalizados que discípulos do New Criticism e da Crítica Humanística construíram em torno da obra de Foucault, Barthes e Derrida, entre outros.

Yvancos propõe, assim, uma "anti-retórica da crise", diametralmente oposta à postura conservadora que confere a determinados textos a qualificação de clássicos, "depositários de um bem cultural uniforme e estável", numa espécie de nostalgia do perdido. Tal idealização de textos e de autores supõe uma universalidade em seu reducionismo ao alocar os textos literários em uma estrutura estanque. $\mathrm{O}$ autor afirma, ainda, que a discussão em torno da crise da teoria não ocorre de maneira reflexiva, mas de forma a reverberar, produzindo dimensões meta-teóricas; e propõe que a força da literariedade consiste, portanto, na resistência a esse enquadramento no cânone. A concepção de Kermode de que a potencialidade do clássico consiste em apresentar coisas distintas a diferentes leitores é adicionada à proposição de Steiner de que o texto clássico é aquele que interroga a diferentes homens, em diferentes épocas.

As teorias sistêmicas parecem interessantes por não caírem na armadilha maniqueísta com a qual esta questão é posta, atentando, ao contrário, para o "desafio epistemológico" por ela configurado. Embora tais teorias revelem grande heterogeneidade - semiótica da cultura de I. Lotman, sociologia da literatura de Bordieu e Jacques Dubois, teoria empírica da 
literatura de S.J. Schmidt e teoria dos polisistemas de EvenZohar -, elas caracterizam, de modo uníssono, o âmbito literário segundo a perspectiva de "polisistemas", isto é, um conjunto de atividades de ordens diversificadas. Pontuam princípios pertinentes tanto à literatura quanto ao cânone literário, como, por exemplo, a impossibilidade de serem definidos estaticamente os dois fenômenos e a necessidade de inter-relação entre diferentes sistemas e códigos sob os quais estejam regidos. Almeja-se uma articulação teórica que privilegie menos os universais estéticos do que os particulares históricos. Sendo assim, a teoria do cânone deve ser pensada a partir de uma base pluralista.

Convém destacar o enorme relevo que Yvancos dispõe para dois teóricos: Lotman e Bordieu. Segundo o teórico espanhol, a produção intelectual de ambos podem oferecer um sólido programa de estudos de base empírica para as investigações sobre a canonicidade literária. A obra "As regras da arte: gêneses e estrutura do campo literário", de Bordieu, por exemplo, aponta para a questão de que quando uma obra obtém um reconhecimento massivo há um depauperamento de sua significação no estrato superior dos entendidos. Um meio prudente então, quando nos referimos ao cânone, seria a necessidade de se fazer à criação de uma gramática projetiva. Tal instrumento abarcaria as obras que possuíssem em cada momento as condições para serem introduzidas nesses elencos por virtude da generalização ou projeção do mesmo principio de legitimidade.

É importante ressaltar que a gramática projetiva não pode seguir um paradigma particular de um momento específico da cultura americana como fez Harold Bloom em sua tentativa de reafirmação dos clássicos, pois, desse modo, não serviria como instrumental metodológico à referida gramática projetiva. 
Lotman foi outro autor que introduziu grandes contribuições à teorização dos clássicos. Segundo ele, o caráter dinâmico do cânone faz que os textos que estejam fora tendam progressivamente a ocupar o centro do sistema e o que está dentro do cânone tenda a se deslocar a um estrato não-canonizado. Também defende que a literatura nunca é um grupo de textos independente do mecanismo de sua auto-organização. Assim, os meta-textos sempre acompanham a literatura como normas, regras e críticas que fazem com que a Literatura volte-se sobre si mesma para se auto-organizar. A essa auto-organização corresponde tanto o mecanismo das exclusões (literário x nã̃o literário) quanto a própria hierarquia interna entre os admitidos no cânone. Corroborando tal afirmativa, Lotman, em La cultura e l'esplosiones: Prevedibilidà e imprevedibilità (1992), descreve o fenômeno da "criatividade" dos textos e o papel dos fatores casuais na literatura, que, segundo ele, os livros inovadores, criativos, não estão em nenhuma língua "o texto antecede a aparição da língua e a estimula" (Lotman, 1989: 92). A tese principal é de que a cultura obriga a uma constante resituação da dialética entre o previsível e o imprevisível. Seus códigos se vêm constantemente sobrepassados por novos textos que introduzem fatores casuais, contrários ao discurso da teoria da literatura e da ciência que tende a um isomorfismo.

O teórico se debruça então sobre as idéias de Godzich, que propõe pensar a escritura do "marginal" (escravos opondo-se à figura do senhor) como um grito pela diferença. A teoria seria, portanto, o espaço de ressonância e amplificação dos gritos de quem nunca teve voz. Tal perspectiva, inserida claramente no horizonte dos conceitos dos Estudos Culturais, opõe-se às idéias de Louis Gates, defensor da constituição de um cânone "negro" aos moldes do cânone "branco". Para Pozuelo, a função da teoria não é administrar os controles para 
que certas vozes sejam ouvidas ou silenciadas, mas denunciar e resistir aos modos como se produzem esses "silêncios".

Além de oferecer à crise um sentido positivo e optar por historicizá-la ao invés de relativizá-la, Yvancos conclui que a teoria deve ser uma espécie de cenário onde as crises não só acontecem quanto podem encontrar melhor espaço para o seu desenvolvimento.

Se aceitarmos, após a leitura desse livro, a premissa de que um cânone nunca é uma antologia pessoal, também passamos a imaginar, como Gabriele Schwab propõe, que literatura pode muito bem ser definida como uma etnografia imaginária. Segundo a teórica, todo ato de leitura é tum encontro com uma cultura ficcional, encontro com o outro, que pode acarretar um processo de expansão, dissolução ou transgressão da própria cultura. Na esteira de Schwab e de Pratt, Yvancos termina a sua reflexão afirmando que a literatura poderia ser considerada como umjogo de"fronteiras movediças", de culturas distintas que se confrontam em relações assimétricas. $\mathrm{E}$ a teoria poderia ser afinal um espaço de complexidade hermenêutica, de reconhecimento, de intercâmbio, e acima de tudo, de discussão das diferenças. 